\title{
PHENOLIC ACIDS AND ANTIOXIDANT ACTIVITY OF WHEAT SPECIES: A REVIEW
}

\author{
L'UDMILA LEVÁKOVÁ*, MAGDALÉNA LACKO-BARTOŠOVÁ
}

Slovak University of Agriculture in Nitra

LEVÁKOVÁ, L'. - LACKO-BARTOŠOVÁ, M.: Phenolic acids and antioxidant activity of wheat species: a review. Agriculture (Pol'nohospodárstvo), vol. 63, 2017, no. 3, p. 92-101.

\begin{abstract}
Wheat (genus Triticum) is considered to be an important source of polyphenols, plant secondary metabolites with numerous health-promoting effects. Many phytochemicals are responsible for the high antioxidant activity of whole grain products. However, there is a lack of information about composition of phenolic acids and their concentrations in different Triticum species. Despite the fact that the increased consumption of whole grain cereals and whole grain-based products has been closely related to reduced risk of chronic diseases, bioactive compounds found in whole grain cereals have not achieved as much attention as the bioactive compounds in vegetables and fruits. Recent studies have revealed that the content of bioactive compounds and antioxidant capacity of whole grain cereals have been regularly undervalued in the literature, because they contain more polyphenols and other phytochemicals than was reported in the past. Phenolic acids represent a large group of bioactive compounds in cereals. These compounds play a significant role in the possible positive effects of the human diet rich in whole grain cereals, especially in wheat and provide health benefits associated with demonstrably diminished risk of chronic disease development. Ferulic acid, the primary and the most abundant phenolic acid contained in wheat grain, is mainly responsible for the antioxidant activity of wheat, particularly bran fraction. In this paper, selected phenolic compounds in wheat, their antioxidant activity and health benefits related to consumption of whole grain cereals are reviewed.
\end{abstract}

Key words: antioxidant activity, health benefits, phenolics, phytochemicals, wheat

Wheat is an important agricultural commodity and a main food all around the world. It is one of the major food grains consumed by people (Van Hung et al. 2009) with global wheat production forecast in 2015 at 735 million tonnes (FAO 2015). It contains important beneficial components for human nutrition. Due to the high content of natural antioxidants, wheat and wheat-based products can perfectly serve as a basis for the functional foods development designed to improve the health of millions of consumers (Vaher et al. 2010). Although wheat is used mainly as a source of energy, whole wheat grains are an excellent source of dietary fiber, vitamins, minerals and other bioactive phytochemicals such as antioxidant compounds (Cai et al. 2014). For this reason, numerous studies have been conducted to investigate the nutritional quality and health benefits of whole wheat grains.

The phenolic compounds, one of the most widely occurring groups of phytochemicals, are secondary metabolites synthesized during the plant development and in response to stress conditions (Brandolini et al. 2013). These compounds, most of which are present in wheat bran fractions, play a significant role in plant growth and reproduction because they provide protection against pests and pathogens and contribute to the colour and sensory characteristics of plant species. In addition to their role in plants, in human diet phenolic compounds provide many health benefits associated with diminished risk of

Ing. Ludmila Leváková (*Corresponding author), prof. Ing. Magdaléna Lacko-Bartošová, CSc., Department of Sustainable Agriculture and Herbology, Faculty of Agrobiology and Food Resources, Slovak University of Agriculture in Nitra, Tr. A. Hlinku 2, 94976 Nitra, Slovak Republic. E-mail: levakova.ludmila@gmail.com 
chronic diseases caused by reactive oxygen species (Harborne \& Williams 2000; Gani et al. 2012).

According to Heim et al. (2002), the beneficial effects of phenolic compounds have been attributed to their antioxidant activity. It depends on the structure, particularly the number and position of the hydroxyl groups and the type of substitutions on the aromatic rings (Balasundram et al. 2006). Phenolics have lower electron reduction potential than the oxy-gen radicals and they are excellent oxygen radical scavengers. Additionally, the phenoxyl radicals are less reactive than the oxygen radicals and they scavenge reactive oxygen intermediates without promoting further harmful oxidative reactions (Ainsworth \& Gillespie 2007). This strong antioxidant activity of phenolic compounds leads to anti-inflammatory, anti-thrombotic, anti-atherogenic, cardioprotective and vasodilatory effects on human health (Quiñones et al. 2013).

The phenolic compounds have the structure that varies from simple molecules to complex polymers. They contain one or more aromatic rings with one or more hydroxyl groups. This crucial structural diversity has an impact on their differences in bioavailability. Simple phenolic acids cross the intestinal barrier more easily, while complex molecules are hardly absorbed (Scalbert et al. 2002). Cereals represent staple food of humankind and are an important source of phenolic compounds. One of the most common types of phenolic compounds in cereals are phenolic acids (Li et al. 2008), which are present in three forms: soluble free, soluble conjugated with mono- and polysaccharides and insoluble bound (Naczk \& Shahidi 2004). According to Li et al. (2008), the most abundant fraction in wheat grains is the insoluble bound (77\%), followed by the soluble conjugated $(22 \%)$ and the soluble free $(<0.5-$ $1 \%)$. In the past, the phenolic content of whole grain cereals had been undervalued in the literature, because most of researches only studied the free phenolic content and not the content of bound phenolics (Adom \& Liu 2002). Phytochemicals in the bound form cannot be digested by human enzymes. They could survive stomach and small intestine digestion and therefore can reach the colon. The colonic microflora may release the bound phytochemicals by fermentation processes and after absorption provide health benefits in colon or other body tissues. This can partly explain the mechanism of consumption of whole grain cereals in the prevention of colon cancer, other gastrointestinal cancers, breast cancer, prostate cancer and other chronic diseases, which is supported by many epidemiological studies (Liu 2007).

\section{Antioxidant activity of phytochemicals in wheat}

The important group of phytochemicals with small molecular weight present in wheat grains are antioxidants. Antioxidants are defined as molecules that can delay or prevent oxidative stress at low concentration and specific assay conditions. Oxidative stress has been related to cardiovascular diseases, cancer and other chronic diseases that account for a major part of deaths today (Willcox et al. 2004; Vaher 2010).

Wheat contains a diverse range of biologically active compounds that may contribute to its antioxidant capacity. Wheat antioxidants are mainly concentrated in bran fraction and the amount of these antioxidants depends on the grain variety (Kim et al. 2006). First of all, wheat bran represents a good source of phenolic acids, which significantly contribute to the total antioxidant activity of wheat (Baublis et al. 2000; Yu et al. 2003; Kosík et al. 2014c). Extract of wheat bran with a high concentration of phenolic acids was shown to have stronger antioxidant activity than other wheat fractions (Onyeneho \& Hettiarachchy 1992). In addition, wheat bran is able to inhibit lipid oxidation catalysed by either peroxyl or iron radicals (Baublis et al. 2000). Most recently, Zhou et al. (2004) reported that wheat grain, bran and other fractions had different antioxidant activities and total phenolic contents. Their research also showed that ferulic acid, with a concentration range of $99-231 \mu \mathrm{g} / \mathrm{kg}$, was the main contributor to the antioxidant activity of wheat. It has been suggested that ferulic acid could be used as a marker of wheat antioxidants. According to Lacko-Bartošová et al. (2013), antioxidant activity of whole grain flour was significantly higher than the white flour. Antioxidant activity of white flour $(23.26 \%)$ was two times lower than antioxidant activity of whole grain flour $(49.57 \%)$. The highest antioxidant activity $(76.47 \%)$ was determined in wheat bran. 
Phytochemicals in wheat exhibit strong antioxidant properties. They scavenge or neutralize free radicals and reduce oxidative damage to DNA, proteins and membrane lipids. Decreases in oxidative damage to cells or cell components may explain the reduction of chronic diseases, which may be caused by oxidative stress (Willcox et al. 2004; Kim \& Kim 2016). To investigate health benefits of wheat, total phenolic contents and antioxidant capacities in wheat have been studied (Verma et al. 2008; Okarter et al. 2010). Adom and Liu (2002) reported that the antioxidant capacity of wheat was higher than that of rice or oats. Verma et al. (2008) found that the antioxidant activity in wheat bran was highly correlated with its free, bound and total phenolic contents. Most of the antioxidant compounds in wheat are bound and may survive digestion to reach the colon intact, where they induce an antioxidant environment (Pérez-Jiménez \& Saura-Calixto 2005). Okarter (2011) found that phenolic extract from the insoluble-bound fraction of whole wheat inhibited the proliferation of human colon cancer cells in vitro. A major action in the protection of colon from cancer probably exert ferulic acid - the typical whole wheat phenolic acid with only $0.5-5 \%$ of absorption within the small intestine. Thus, phenolic acids in the bound form can act along the whole length of the digestive tract by trapping oxidative compounds (Fardet 2010).

\section{Phenolic acids}

Phenolic acids are derivatives of benzoic and cinnamic acids and are present in all cereals. They can be subdivided into two major groups, hydroxybenzoic acid and hydroxycinnamic acid derivatives (Figure 1). Hydroxybenzoic acid derivatives include $p$-hydroxybenzoic, protocatechuic, vannilic, syringic and gallic acids. Hydroxycinnamic acid derivatives include $p$-coumaric, caffeic, ferulic and sinapic acids (Figure 1) (Mattila et al. 2005; Gani et al. 2012). The common phenolic acids found in whole grain cereals include ferulic acid, vanillic acid, caffeic acid, syringic acid and $p$-coumaric acid (Sosulski et al. 1982; Liu 2007). Ferulic acid is the primary and the most abundant phenolic acid in wheat grains. Smaller concentrations of $p$-hydroxybenzoic, $o$-coumaric, $p$-coumaric, vanillic, syringic, salicylic and sinapic acids are also present in wheat (Moore et al. 2005; Liyana-Pathirana et al. 2006).
Composition, content and effects of food processing

The phenolic acids reported in cereals occur in both free and bound form. Free phenolic acids are found in outer layers of the pericarp. Bound phenolic acids are esterified to cell walls and released from the cell matrix by acid or base hydrolysis (Mattila et al. 2005; Gani et al. 2012). Phenolic acids in wheat grains are present mostly in the bound form with other grain components such as saccharides starch, cellulose, $\beta$-glucan and pentosane (Yu et al. 2001; Vaher et al. 2010). Also, food processing, such as fermentation, thermal processing, pasteurisation and freezing, contributes to the release of these bound phenolic acids (Dewanto et al. 2002). They can be degraded at high temperature and high pH, particularly caffeic acid (Dimberg et al. 2001).

Phenolic acids are predominantly present in the bran, i.e. the aleurone layer and the outermost pericarp, which are usually eliminated during milling (Bondia-Pons et al. 2009; Belobrajdic \& Bird, 2013). As a result, whole meal flours contain higher amounts of phenolic acids than commercial wheat flours. In whole meal flours, the number of polyphenols is highly variable and is closely related to species and variety of cereals (Adom et al. 2005; Andersson et al. 2014; Kosík et al. 2014b). Different extraction conditions also influence the content reported in different studies (Yu et al. 2001).

Einkorn is a high-nutritional-value cereal with the high content of proteins, carotenoids and tocols (Hidalgo et al. 2006; Brandolini et al. 2008). However, a significant gap remains in its phenolic acid composition. Li et al. (2008) recorded a total phenolic acid content similar to winter, spring and durum wheats, slightly higher than spelt, but marginally lower than emmer. Serpen et al. (2008) measured higher values of bound ferulic acid in emmer than in einkorn. However, Abdel-Aal and Rabalski (2008) reported more phenolic acids in einkorn than in several primitive and modern wheat species. According to HEALTHGRAIN diversity screen, the large EU project, the content of phenolic acids in wheat species varied between 326 and $1171 \mu \mathrm{g} / \mathrm{g}$ dry matter (DM) (Li et al. 2008). Other studies have revealed that the total concentrations of phenolic acids are typically in the range of $200-900 \mu \mathrm{g} / \mathrm{g}$ DM in whole grain wheat (Belobrajdic \& Bird 2013). The content of phenolic acids in spelt also showed differences 
between varieties and ranged from 507 to $1257 \mu \mathrm{g} / \mathrm{g}$ DM (Gawlik-Dziki et al. 2012). Some studies have concluded that the content of phenolic acids is related to genotype (Hernández et al. 2011; Ragaee et al. 2012). However, others have found that location (i.e. environmental factors) is more important (Vaher et al. 2010).

The conjugated and bound phenolic acids recorded in selected wheat species are summarise in the Table 1. In the study of Brandolini et al. (2013), 39 different Triticum monococcum, T. turgidum and T. aestivum accessions were evaluated. The total conjugated phenolic acids in whole meal flour ranged between 36.0 and
$52.6 \mathrm{mg} / \mathrm{kg}$ DM. The total bound phenolic acids varied between 441 and $715 \mathrm{mg} / \mathrm{kg}$ DM that correspond with the results (208-964 mg/kg DM) reported by Li et al. (2008). Volkan et al. (2015) analysed 15 wheat accessions from different Triticum species. The phenolic acid contents in the conjugated and bound extracts varied between $28.2-70.8 \mathrm{mg} / \mathrm{kg}$ DM and $482-766 \mathrm{mg} / \mathrm{kg}$ DM, respectively. Hidalgo and Brandolini (2017) tested conjugated and bound phenolic acids content of three einkorn accessions. The total conjugated phenolic acids ranged between 33.9 and $54.9 \mathrm{mg} / \mathrm{kg}$ DM. The concentrations of total bound phenolic acids varied between 484.2 and $579.5 \mathrm{mg} / \mathrm{kg}$ DM.

a<smiles>[R]c1cc(C(=O)O)cc([R])c1[R]</smiles>

\begin{tabular}{lccc}
\hline Benzoic acid & \multicolumn{3}{c}{ Substitutions } \\
\cline { 2 - 4 } derivatives & $\mathrm{R}_{1}$ & $\mathrm{R}_{2}$ & $\mathrm{R}_{3}$ \\
\hline Benzoic acid & $\mathrm{H}$ & $\mathrm{H}$ & $\mathrm{H}$ \\
\hline p-Hydroxybenzoic acid & $\mathrm{H}$ & $\mathrm{OH}$ & $\mathrm{H}$ \\
\hline Protocatechuic acid & $\mathrm{H}$ & $\mathrm{OH}$ & $\mathrm{OH}$ \\
\hline Vannilic acid & $\mathrm{CH}_{3} \mathrm{O}$ & $\mathrm{OH}$ & $\mathrm{H}$ \\
\hline Syringic acid & $\mathrm{CH}_{3} \mathrm{O}$ & $\mathrm{OH}$ & $\mathrm{CH}_{3} \mathrm{O}$ \\
\hline Gallic acid & $\mathrm{OH}$ & $\mathrm{OH}$ & $\mathrm{OH}$ \\
\hline
\end{tabular}

b

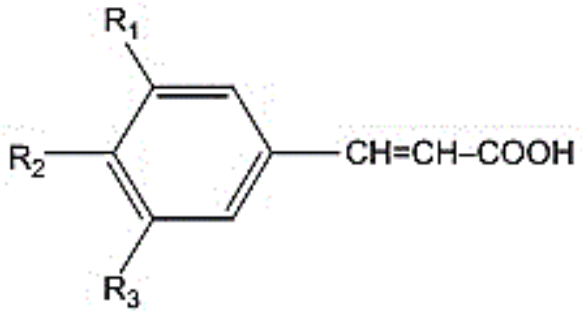

\begin{tabular}{lccc}
\hline Cinnamic acid & \multicolumn{3}{c}{ Substitutions } \\
\cline { 2 - 4 } derivatives & $\mathrm{R}_{1}$ & $\mathrm{R}_{2}$ & $\mathrm{R}_{3}$ \\
\hline Cinnamic acid & $\mathrm{H}$ & $\mathrm{H}$ & $\mathrm{H}$ \\
\hline p-Coumaric acid & $\mathrm{H}$ & $\mathrm{OH}$ & $\mathrm{H}$ \\
\hline Caffeic acid & $\mathrm{OH}$ & $\mathrm{OH}$ & $\mathrm{H}$ \\
\hline Ferulic acid & $\mathrm{CH}_{3} \mathrm{O}$ & $\mathrm{OH}$ & $\mathrm{H}$ \\
\hline Sinapic acid & $\mathrm{CH}_{3} \mathrm{O}$ & $\mathrm{OH}$ & $\mathrm{CH}_{3} \mathrm{O}$ \\
\hline
\end{tabular}

Figure 1. Structure of common phenolic acids: (a) benzoic acid derivatives and (b) cinnamic acid derivatives (Liu 2007) 
Although the content of phenolic acids depends on variety and various agricultural practices, it seems that bound phenolic acids variation is lower in different growing conditions than free and conjugated forms (Fernandez-Orozco et al. 2010; Belobrajdic \& Bird 2013; Kosík et al. 2014a). Organic cultivation systems have been found to lead to a small increase in the total amount of phenolic acids, especially ferulic and $p$-coumaric acid, in spring and winter wheats, compared with conventionally grown wheat (Zuchowski et al. 2011). These differences were attributed to a concentration effect due to differences in the size of the grain, which was smaller in organically grown crops. It is also important to note that the study was performed on plants grown within the two cropping systems only in one year (Andersson et al. 2014).

Both free and bound phenolic acids are affected by processing, e.g. baking. A study performed by El-Sayed and Rabalski (2013) found that baked products contained higher amounts of free phenolic acids and lower amounts of bound ones than the whole grain wheat flour used. This is probably the result of release of bound compounds. Most of the changes occurred during baking, but no change could be seen in the dough. In other studies, baking has resulted in a reduced amount of free phenolic acids, although in those studies a fermentation process preceded the baking process, which might explain the differences in the results (Menga et al. 2010). The free phenolic acids also increased and actually seemed to be more stable in biscuits and muffins than in bread products. El-Sayed and Ra- balski (2013) explained this by the fact that phenolic acids are less accessible to oxidation in fat products than in aqueous food systems. However, different mechanisms may occur simultaneously in the cereal products during processing, influencing the content of various phenols. Concurrently to release of bound compounds from the food matrix, phenols may be oxidised, polymerised or thermally degraded.

\section{Bioactivity and implications for human health}

Some studies have been conducted to evaluate the bioavailability of hydroxycinnamates from cereals and it has been found that esterification of ferulic acids impairs their uptake in the intestine (Belobrajdic \& Bird 2013). However, colonic fermentation in the digestive tract releases phenolic compounds, which in turn may be taken up in the large intestine (Maki et al. 2012). Zhao and Moghadasian (2010) suggested that the bioavailability of hydroxycinnamic acids follow the order $p$-coumaric acid $>$ ferulic acid $>$ caffeic acid, and that the free compounds have higher bioavailability than their corresponding bound forms. The metabolism of these compounds in the colon is not fully understood, but it is supposed that they undergo reduction, dihydroxylation, demethylation and $\beta$-oxidation.

Phenolic acids have many functions in cereals. They act as stabilisers of the cell wall structure, but they may also be involved in the physical and chemical defence against various microorganisms, pests and insects. Phenolic acids have also been reported to inhibit the biosynthesis of trichothecenes of Fusarium fungi, which are potent human toxins (Boutigny et al. 2009). They are mentioned as bio-

$\mathrm{T} \quad \mathrm{a} \quad \mathrm{b} \quad 1 \quad \mathrm{e} \quad 1$

Soluble conjugated, insoluble bound and total phenolic acids in selected wheat species $[\mathrm{mg} / \mathrm{kg} \mathrm{DM}]$

\begin{tabular}{|l|c|c|c|}
\hline \multirow{2}{*}{ Species } & \multicolumn{2}{|c|}{ Phenolic acids } & Total \\
\cline { 2 - 4 } & Soluble conjugated & Insoluble bound & $516-831$ \\
\multirow{2}{*}{ Einkorn ${ }^{\mathrm{a}, \mathrm{b}, \mathrm{c}}$} & $34.4-63.9$ & $482-766$ & $578-634$ \\
& $43.8-54.9$ & $534.1-579.5$ & 637 \\
\hline \multirow{2}{*}{ Emmer ${ }^{\mathrm{a}, \mathrm{c}}$} & 52.6 & 584 & 551 \\
& 44.3 & 506 & 596 \\
\hline \multirow{2}{*}{ Spelt } & 49.9 & 546 & 578 \\
& 39.7 & 538 & 637 \\
\hline
\end{tabular}

${ }^{a}$ Volkan et al. (2015); ${ }^{b}$ Hidalgo \& Brandolini (2017); ${ }^{\circ}$ Brandolini et al. (2013)

DM - dry matter 
active phytochemicals promoting human health in a multidisciplinary way. They may provide health benefits because of their antioxidant properties (Thompson 1994; Bondia-Pons et al. 2009). Ragaee et al. (2012) found a high correlation between the concentration of bound phenolic acids in whole grain wheat and DPPH (diphenylpicrylhydrazyl) scavenging capacity. Phenolic acids may also inhibit LDL-cholesterol oxidation (low density lipoproteins) and oxidative damage to DNA and lipid membranes, which might otherwise lead to several pathological conditions, including cardiovascular diseases, type 2 diabetes and cancer. In vitro studies on phenolic acids have shown anti-inflammatory effects and anti-proliferative activities on cancer cells. Several phenolic acids have also been shown to be responsible for inhibiting cataracts of the eye lens (Chethan et al. 2008).

\section{Ferulic and p-coumaric acid in cereals}

Ferulic acid (trans-4-hydroxy-3-methoxycinnamic acid) is the most abundant hydroxycinnamic acid found in cereal grains. It occurs primarily in the plant seeds and leaves, mainly covalently conjugated to mono- and disaccharides, plant cell wall polysaccharides, glycoproteins, polyamines and lignin. Wheat bran is considered to be a good source of ferulic acid, which is esterified to hemicellulose of the cell walls (Dewanto et al. 2002). The content of ferulic acid in wheat grains is near to $0.8-2 \mathrm{~g} / \mathrm{kg}$ dry weight basis that represents up to $90 \%$ of total phenolic compounds (Sosulski et al. 1982; Lempereur et al. 1997; Gani et al. 2012).

Ferulic acid in cereals can be found in free, soluble-conjugated and bound forms. About 90$95 \%$ of the total amount of ferulic acid represent the insoluble bound ferulic acid (Lv et al. 2012). The content of bound ferulic acid was significantly higher than free and soluble-conjugated ferulic acid in wheat, corn, oats and rice. The ratio of free, soluble-conjugated and bound ferulic acid in corn and wheat was $0.1: 1: 100$. The order of total ferulic acid content among the tested grains was corn $>$ wheat $>$ oats $>$ rice (Adom \& Liu 2002; Boz 2015). In wheat, the insoluble dietary fraction contains $3544 \mu \mathrm{g} / \mathrm{g}$ of phenols, whereas the soluble fraction contains $95 \mu \mathrm{g} / \mathrm{g}$. This may in- dicate that ferulic acid is bound to arabinoxylan but not to $\beta$-glucan, which is a more soluble polysaccharide (Caprita et al. 2011). The content of ferulic acid seems to be higher in soft wheat than in hard wheat (Ragaee et al. 2012).

Ferulic acid and other phenolic acids protect wheat kernels by providing both physical and chemical barriers through cross-linking saccharides, antioxidant activities against destructive radicals and astringency that deters insects and animals from consumption (Arnason et al. 1992; Liu 2007). Like several other phenolic compounds, ferulic acid exhibits antioxidant activity in response to free radicals via donating one hydrogen atom from its phenolic hydroxyl group (Kumar \& Pruthi 2014). Beneficial effects on human health such as anti-inflammation and free radical scavenging have been demonstrated. It has been suggested that ferulic acid can treat diverse disorders including Alzheimer's disease, cardiovascular diseases, diabetes mellitus, cancer and skin diseases (Mancuso \& Santangelo 2014; Karunaratne \& Zhu 2016). Suzuki et al. (2007) found that ferulic acid may have positive effects on blood pressure through stimulation of nitric acid production, which induces arterial vasodilation and increases the blood flow.

$p$-coumaric acid (4-hydroxycinnamic acid) is a hydroxyl derivative of cinnamic acid (Garrait et al. 2006). It is present in the lowest amount in the centre of the kernels and in increasing amount towards the outer layers (Awika \& Rooney 2004; Madhujith et al. 2006). This acid is another phenolic acid of great interest due to its chemoprotectant and antioxidant properties (Torres y Torres \& Rosazza 2001). It has been suggested to have anti-tumour activity against human malignant tumours. There is a report revealing that $p$-coumaric acid reduces the risk of stomach cancer (Ferguson et al. 2005). It has also potentially protective effect against heart diseases because of its ability to decrease the resistance of LDL lipoproteins, cholesterol oxidation and lipid peroxidation (Garrait et al. 2006). It shows anti-mutagenesis, anti-genotoxicity and anti-microbial activities, inhibits cellular melanogenesis and plays a role in immune regulation in humans (Kiliça \& Yeşiloğlub 2013). 


\section{CONCLUSIONS}

Whole grain cereals may represent a significant share in intake of bioactive compounds in human diet. They are mainly present in bran fraction of cereals, which is usually eliminated by milling. Growing evidence indicates that the consumption of whole grains at regular intervals can be related to many health benefits, for example the reduced risk of cardiovascular diseases, obesity, type 2 diabetes and certain types of cancer. Bioactive compounds play an important role in plant growth, protection against pathogens and pests, affect the colour and sensory properties of plants. Despite this fact, antioxidant properties of cereals reported in the literature have been undervalued, since only unbound forms have been studied. Most of the bioactive compounds in wheat are in the insoluble bound fraction and may survive gastrointestinal digestion. They can be released from cell matrix by acid or base hydrolysis, usually by colonic microflora through fermentation. The antioxidant potential of whole grains is closely related to their phenolic content, primarily ferulic acid as the main source of antioxidant activity. Einkorn, emmer and spelt wheat belong to the non-traditional wheat species with different valuable traits and properties. Significant gap remains in their antioxidant activities, phenolic acid composition and the possible role in human diet. More knowledge is needed to prepare strong arguments for an increased consumption of whole grain cereals and whole grain-based products and to provide better information about their health benefits. For this reason, the study of bioactive compounds reviewed in this paper is constantly important issue.

Acknowledgements. The research presented in this paper was supported by the project ITEBIO "Support and innovations of a special and organic products technologies for human healthy nutrition" ITMS: 26220220 115, implemented under Operational Programme Research and Development.

\section{REFERENCES}

ABDEL-AAL, E.-S.M. - RABALSKI, I. 2008. Bioactive compounds and their antioxidant capacity in selected primitive and modern wheat species. In The Open Agriculture Journal, vol. 2, no. 9, pp. 7-14. DOI: 10.2174/1874331500802010007 ADOM, K.K. - LIU, R.H. 2002. Antioxidant activity of grains. In Journal of Agricultural and Food Chemistry, vol. 50, no. 21, pp. 6182-6187. DOI: 10.1021/jf0205099

ADOM, K.K. - SORRELLS, M.E. - LIU, R.H. 2005. Phytochemical and antioxidant activity of milled fractions of different wheat varieties. In Journal of Agricultural and Food Chemistry, vol. 53, no. 6, pp. 2297-2306. DOI: 10.1021/ jf048456d

AINSWORTH, E.A. - GILLESPIE, K.M. 2007. Estimation of total phenolic content and other oxidation substrates in plant tissues using Folin-Ciocalteu reagent. In Nature Protocols, vol. 2 , no. 4, pp. 875-877. DOI: 10.1038/nprot.2007.102

ANDERSSON, A.A.M. - DIMBERG, L. - ÅMAN, P. LANDBERG, R. 2014. Recent findings on certain bioactive components in whole grain wheat and rye. In Journal of Cereal Science, vol. 59, no. 3, pp. 294-311. DOI: 10.1016/j. jes.2014.01.003

ARNASON, J.T. - GALE, J. - CONILH DE BEYSSAC, B. - SEN, A. - MILLER, S.S. - PHILOGENE, B.J.R. LAMBERT, J.D.H. - FULCHER, R.G. - SERRATOS, A. - MIHM, J. 1992. Role of phenolics in resistance of maize grain to stored grain insects, Prostphanus truncatus (Horn) and Sitophilus zeamais (Motsch). In Journal of Stored Products and Research, vol. 28, no. 2, pp. 119-126. DOI: 10.1016/0022-474X(92)90019-M

AWIKA, J.M. - ROONEY, L.W. 2004. Sorghum phytochemicals and their potential impact on human health. In Phytochemistry, vol. 65, no. 9, pp. 1199-1221. DOI: 10.1016/j. phytochem.2004.04.001

BALASUNDRAM, N. - SUNDRAM, K. - SAMMAN, S. 2006. Phenolic compounds in plants and agri-industrial by-products: Antioxidant activity, occurrence, and potential uses. In Food Chemistry, vol. 99, no. 1, pp. 191-203. DOI: 10.1016/j.foodchem.2005.07.042

BAUBLIS, A.J. - DECKER, E.A. - CLYDESDALE, F.M. 2000. Antioxidant effect of aqueous extracts from wheat based ready-to-eat breakfast cereals. In Food Chemistry, vol. 68, no. 1, pp. 1-6. DOI: 10.1016/S0308-8146(99)00142-9

BELOBRAJDIC, D.M. - BIRD, A.R. 2013. The potential role of phytochemicals in wholegrain cereals for the prevention of type-2 diabetes. Review. In Nutrition Journal, vol. 12, no. 62 , pp. $62-73$. DOI: $10.1186 / 1475-2891-12-62$

BONDIA-PONS, I. - AURA, A.M. - VUORELA, S. KOLEHMAINEN, M. - MYKKÄNEN, H. - POUTANEN, K. 2009. Review: rye phenolics in nutrition and health. In Journal of Cereal Science, vol. 49, no. 3, pp. 323-336. DOI: 10.1016/j.jcs.2009.01.007

BOUTIGNY, A.L. - BARREAU, C. - ATANASOVA-PENICHON, V. - VERDAL-BONNIN, M.N. - PINSON-GADAIS, L. - RICHARD-FORGET, F. 2009. Ferulic acid, an efficient inhibitor of type B trichothecene biosynthesis and Tri gene expression in Fusarium liquid cultures. In $M y$ cological Research, vol. 113 , no. 6-7, pp. 746-753. DOI: 10.1016/j.mycres.2009.02.010

BOZ, H. 2015. Ferulic acid in cereals: A review. In Czech Journal of Food Sciences, vol. 33, no. 1, pp. 1-7. DOI: 10.17221/401/2014-CJFS

BRANDOLINI, A. - CASTOLDI, P. - PLIZZARI, L. - HIDALGO, A. 2013. Phenolic acids composition, total polyphenols content and antioxidant activity of Triticum monococcum, Triticum turgidum and Triticum aestivum: A two-years evaluation. In Journal of Cereal Science, vol. 58, no. 1, pp. 123-131. DOI: 10.1016/j.jcs.2013.03.011

BRANDOLINI, A. - HIDALGO, A. - MOSCARITOLO, S. 2008. Chemical composition and pasting properties of einkorn (Triticum monococcum L. subsp. monococcum) 
whole meal flour. In Journal of Cereal Science, vol. 47, no 3, pp. 599-609. DOI: 10.1016/j.jcs.2007.07.005

CAI, L. - CHOI, I. - LEE, C.K. - PARK, K.K. - BAIK, B.K. 2014. Bran characteristics and bread-baking quality of whole grain wheat flour. In Cereal Chemistry, vol. 91, no. 4, pp. 398-405. DOI: 10.1094/CCHEM-09-13-0198-R

CAPRITA, R. - CAPRITA, A. - CRETESCU, I. 2011. Effect of extraction conditions on the solubility of non-starch polysaccharides of wheat and barley. In Journal of Food, Agriculture and Environment, vol. 9, no. 3-4, pp. 41-43.

CHETHAN, S. - DHARMESH, S.M. - MALLESHI, N.G 2008. Inhibition of aldose reductase from cataracted eye lenses by finger millet (Eleusine coracana) polyphenols. In Bioorganic and Medicinal Chemistry, vol. 16, no. 23, pp. 10085-10090. DOI: 10.1016/j.bmc.2008.10.003

DEWANTO, V. - WU, X.Z. - LIU, R.H. 2002. Processed sweet corn has higher antioxidant activity. In Journal of Agricultural and Food Chemistry, vol. 50, no. 17, pp. 4959-4954. DOI: $10.1021 / \mathrm{jf0} 55537$

DIMBERG, L.H. - SUNNERHEIM, K. - SUNDBERG, B. WALSH, K. 2001. Stability of oat avenanthramides. In $\mathrm{Ce}$ real Chemistry, vol. 78, no. 3, pp. 278-281. DOI: 10.1094/ CCHEM.2001.78.3.278

EL-SAYED, M.A.-A. - RABALSKI, I. 2013. Effect of baking on free and bound phenolic acids in wholegrain bakery products. In Journal of Cereal Science, vol. 57, no. 3, pp. 312-318. DOI: 10.1016/j.jcs.2012.12.001

FAO (Food and Agriculture Organization of the United Nations), 2015. Food Outlook. Available at http://www.fao. org/3/a-I5003E.pdf. (accessed June 26, 2017)

FARDET, A. 2010. New hypotheses for the health-protective mechanisms of whole-grain cereals: what is beyond fibre? In Nutrition Research Reviews, vol. 23, no. 1, pp. 65-134. DOI: $10.1017 / \mathrm{S} 0954422410000041$

FERGUSON, L.R. - ZHU, S.T. - HARRIS, P.J. 2005. Antioxidant and antigenotoxic effects of plant cell wall hydroxycinnamic acids in cultured HT-29 cells. In Molecular $\mathrm{Nu}$ trition \& Food Research, vol. 49, no. 6, pp. 585-593. DOI: $10.1002 / \mathrm{mnfr} .200500014$

FERNANDEZ-OROZCO, R. - LI, L. - HARFLETT, C. 2010. Effects of environment and genotype on phenolic acids in wheat in the HEALTHGRAIN diversity screen. In Journal of Agricultural and Food Chemistry, vol. 58, no. 17, pp. 9341-9352. DOI: 10.1021/jf102017s

GANI, A. - WANI, S.M. - MASOODI, F.A. - HAMEED, G. 2012. Whole-Grain Cereal Bioactive Compounds and Their Health Benefits: A Review. In Journal of Food Processing \& Technology, vol. 3, no. 3, pp. 1-10. DOI: 10.4172/21577110.1000146

GARRAIT, G. - JARRIGE J.F. - BLANQUET, S. - BEYSSAC, E. - CARDOT, J.M. - ALRIC, M. 2006. Gastrointestinal absorption and urinary excretion of trans-cinnamic and p-coumaric acids in rats. In Journal of Agricultural and Food Chemistry, vol. 54, no. 8, pp. 2944-2950. DOI: 10.1021/jf053169a

GAWLIK-DZIKI, U. - SWIECA, M. - DZIKI, D. 2012. Comparison of phenolic acid profile and antioxidant potential of six varieties of spelt (Triticum spelta L.). In Journal of Agricultural and Food Chemistry, vol. 60, no. 18, pp. 46034612. DOI: $10.1021 / \mathrm{jf3011239}$

HARBORNE, J.B. - WILLIAMS, C.A. 2000. Advances in flavonoid research since 1992. In Phytochemistry, vol. 55, no 6, pp. 481-504. DOI: 10.1016/S0031-9422(00)00235-1

HEIM, K.E. - TAGLIAFERRO, A.R. - BOBILYA, D.J. 2002. Flavonoid antioxidants: chemistry, metabolism and structure-activity relationships. In The Journal of Nutritional
Biochemistry, vol. 13, no. 10, pp. 572-584. DOI: 10.1016/ S0955-2863(02)00208-5

HERNÁNDEZ, L. - AFONSO, D. - RODRÍGUES, E.M. DIAZ, C. 2011. Phenolic compounds in wheat grain cultivars. In Plant Foods for Human Nutrition, vol. 66, no. 4, pp. 408-415. DOI: $10.1007 / \mathrm{s} 11130-011-0261-1$

HIDALGO, A. - BRANDOLINI, A. 2017. Nitrogen fertilisation effects on technological parameters and carotenoid, tocol and phenolic acid content of einkorn (Triticum monococcum L. subsp. monococcum): A two-year evaluation. In Journal of Cereal Science, vol. 73, pp. 18-24. DOI: https:// doi.org/10.1016/j.jcs.2016.11.002

HIDALGO, A. - BRANDOLINI, A. - POMPEI, C. - PISCOZZI, R. 2006. Carotenoids and tocols of einkorn wheat (Triticum monococcum ssp. monococcum L.). In Journal of Cereal Science, vol. 44, no. 2, pp. 182-193. DOI: 10.1016/j. jcs.2006.06.002

KARUNARATNE, R. - ZHU, F. 2016. Physicochemical interactions of maize starch with ferulic acid. In Food Chemistry, vol. 199 , pp. 372-379. DOI: 10.1016/j.foodchem.2015.12.033

KILIÇA, I. - YEŞILOĞLUB, Y. 2013. Spectroscopic studies on the antioxidant activity of $p$-coumaric acid. In Spectrochimica Acta Part A: Molecular and Biomolecular Spectroscopy, vol. 115, pp. 719-724. DOI: 10.1016/j.saa.2013.06.110

KIM, K.H. - TSAO, R. - YANG, R. - CUI, S.W. 2006. Phenolic acid profiles and antioxidant activities of wheat bran extracts and the effect of hydrolysis conditions. In Food Chemistry, vol. 95, no. 3, 466-473. DOI: 10.1016/j.foodchem.2005.01.032

KIM, M.J. - KIM, S.S. 2016. Antioxidant and antiproliferative activities in immature and mature wheat kernels. In Food Chemistry, vol. 196, pp. 638-645. DOI: 10.1016/j.foodchem.2015.09.095

KOSÍK, T. - LACKO-BARTOŠOVÁ, M. - KOBIDA, L'. 2014a. Free phenol content and antioxidant activity of winter wheat in sustainable farming systems. In Journal of Microbiology, Biotechnology and Food Sciences, vol. 3, special issue 3, pp. 247-249.

KOSÍK, T. - LACKO-BARTOŠOVÁ, M. - KOBIDA, L'. $2014 \mathrm{~b}$. Influence of agricultural practices on phenolics and flavonoids of winter wheat. In BELLEROVÁ, B. - CHLE$\mathrm{BO}, \mathrm{P}$. (Eds.) Inovácie technológii špeciálnych výrobkov biopotravín pre zdravú výżivu l'udí. Nitra: Slovak University of Agriculture, pp. 145-151. ISBN 978-80-552-1272-2

KOSÍK, T. - LACKO-BARTOŠOVÁ, M. - KOBIDA, L'. $2014 \mathrm{c}$. Influence of agricultural practices on phenols and antioxidant activity of winter wheat. In BELLEROVÁ, B. - CHLEBO, P. (Eds.) Inovácie technológií špeciálnych výrobkov biopotravín pre zdravú výživu l'udí. Nitra : Slovak University of Agriculture, pp. 152-158. ISBN 978-80-552$1272-2$

KUMAR, N. - PRUTHI, V. 2014. Potential applications of ferulic acid from natural sources. In Biotechnology Reports, vol. 4, pp. 86-93. DOI: 10.1016/j.btre.2014.09.002

LACKO-BARTOŠOVÁ, M. - KOSÍK, T. - KOBIDA, L. 2013. Free flavonoid content and antioxidant activity of winter wheat in sustainable farming systems. In Journal of Microbiology, Biotechnology and Food Sciences, vol. 2, special issue 1, pp. 2099-2107.

LEMPEREUR, I. - ROUAU, X. - ABECASSIS, J. 1997. Genetic and agronomic variation in arabinoxylan and ferulic acid contents of durum wheat (Triticum durum L.) grain and its milling fractions. In Journal of Cereal Science, vol. 25, no. 2, pp. 103-110. DOI: 10.1006/jcrs.1996.0090

LI, L. - SHEWRY, R. - WARD, J.L. 2008. Phenolic acids in wheat varieties in the Healthgrain diversity screen. In Jour- 
nal of Agricultural and Food Chemistry, vol. 56, no. 21, pp. 9732-9739. DOI: 10.1021/jf801069s

LIU, R.H. 2007. Whole grain phytochemicals and health. In Journal of Cereal Science, vol. 46, no. 3, pp. 207-219. DOI: 10.1016/j.jcs.2007.06.010

LIYANA-PATHIRANA, C. - DEXTER, J. - SHAHIDI, F. 2006. Antioxidant Properties of Wheat as Affected by Pearling. In Journal of Agricultural and Food Chemistry, vol. 54, no. 17, pp. 6177-6184. DOI: 10.1021/jf060664d

LV, J. - YU, L. - LU, Y. - NIU, Y. - LIU, L. - COSTA, J. YU, L. 2006. Phytochemical compositions, and antioxidant properties, and antiproliferative activities of wheat flour. In Food Chemistry, vol. 135, no. 2, pp. 325-331. DOI: 10.1016/J.FOODCHEM.2012.04.141

MADHUJITH, T. - IZYDORCZYK, M. - SHAHIDI, F. 2006. Antioxidant Properties of Pearled Barley Fractions. In Journal of Agricultural and Food Chemistry, vol. 54, no. 9, pp. 3283-3289. DOI: $10.1021 /$ jf0527504

MAKI, K.C. - GIBSON, G.R. - DICKMANN, R.S. - KENDALL, C.W.C. - CHEN, C.Y.O. - COSTABILE, A. COMELLI, E.M. - MCKAY, D.L. - ALMEIDA, N.G. JENKINS, D. - ZELLO, G.A. - BLUMBERG, J.B. 2012. Digestive and physiologic effects of a wheat bran extract, arabino-xylan-oligosaccharide, in breakfast cereal. In $\mathrm{Nu}$ trition, vol. 28, no. 11-12, pp. 1115-1121. DOI: 10.1016/j. nut.2012.02.010

MANCUSO, C. - SANTANGELO, R. 2014. Ferulic acid: Pharmacological and toxicological aspects. In Food and Chemical Toxicology, vol. 65, pp. 185-195. DOI: 10.1016/j. fct.2013.12.024

MATTILA, P. - PIHLAVA, J.M. - HELlSTRÖM, J. 2005. Contents of phenolic acids, alkyl- and alkenylresorcinols, and avenanthramides in commercial grain products. In Journal of Agricultural and Food Chemistry, vol. 53, no. 21, pp. 8290-8295. DOI: $10.1021 /$ jf051437z

MENGA, V. - FARES, C. - TROCCOLI, A. - CATTIVELLI, L. - BAIANO, A. 2010. Effects of genotype, location and baking on the phenolic content and some antioxidant properties of cereal species. In International Journal of Food Science and Technology, vol. 45, no. 1, pp. 7-16. DOI: 10.1111/j.1365-2621.2009.02072.x

MOORE, J. - HAO, Z. - ZHOU, K. - LUTHER, M. - COSTA, J. - YU, L.L. 2005. Carotenoid, tocopherol, phenolic acid, and antioxidant properties of maryland-grown soft wheat. In Journal of Agricultural and Food Chemistry, vol. 53, no. 17, pp. 6649-6657. DOI: 10.1021/jf050481b

NACZK, M. - SHAHIDI, F. 2004. Extraction and analysis of phenolics in food. In Journal of Chromatography A, vol. 1054 , no. $1-2$, pp. 95-111. DOI: 10.1016/S00219673(04)01409-8

OKARTER, N. 2011. Phenolic extracts from insoluble-bound fraction of whole wheat inhibit the proliferation of colon cancer cells. In Life Sciences and Medicine Research, vol. 38 , pp. $1-10$.

OKARTER, N. - LIU, C.-S. - SORRELLS, M.E. - LIU, R.H. 2010. Phytochemical content and antioxidant activity of six diverse varieties of whole wheat. In Food Chemistry, vol. 119 , no. 1 , pp. 249-257. DOI: $10.1016 /$ j.foodchem.2009.06.021

ONYENEHO, S.N. - HETTIARACHCHY, N.S. 1992. Antioxidant activity of durum wheat bran. In Journal of Agricultural and Food Chemistry, vol. 40, no. 9, pp. 1496-1500. DOI: 10.1021/jf00021a005

PÉREZ-JIMENÉZ, J. - SAURA-CALIXTO, F. 2005. Literature data may underestimate the actual antioxidant capacity of cereals. In Journal of Agricultural and Food Chemistry, vol. 53, no. 12, pp. 5036-5040. DOI: 10.1021/jf050049u
QUIÑONES, M. - MIGUEL, M. - ALEIXANDRE, A. 2013. Beneficial effects of polyphenols on cardiovascular disease. In Pharmacological Research, vol. 68, no. 1, pp. 125-131. DOI: $10.1016 /$ j.phrs.2012.10.018

RAGAEE, S. - GUZAR, I. - ABDEL-AAL, E.-S.M. SEETHARAMAN, K. 2012. Bioactive components and antioxidant capacity of Ontario hard and soft wheat varieties. In Canadian Journal of Plant Science, vol. 92, no. 1, pp. 19-30. DOI: 10.4141/cjps2011-100

SCALBERT, A. - MORAND, C. - MANACH, C. - RÉMÉSY, C. 2002. Absorption and metabolism of polyphenols in the gut and impact on health. In Biomedicine \& Pharmacotherapy, vol. 56, no. 6, pp. 276-282.

SERPEN, A. - GÖKMEN, V. - KARAGÖZ, A. - KÖKSEL, H. 2008. Phytochemical quantification and total antioxidant capacities of emmer (Triticum dicoccum Schrank) and einkorn (Triticum monococcum L.) wheat landraces. In Journal of Agricultural and Food Chemistry, vol. 56, no. 16, pp. 7285-7292. DOI: 10.1021/jf8010855

SOSULSKI, F. - KRYGIER, K. - HOGGE, L. 1982. Free, esterified, and insoluble-bound phenolic acids. 3. Composition of phenolic acids in cereal and potato flours. In Journal of Agriculture and Food Chemistry, vol. 30, no. 2, pp. 337-340. DOI: 10.1021/jf00110a030

SUZUKI, A. - YAMAMOTO, M. - JOKURA, H. - FUJII, A. - TOKIMITSU, I. - HASE, T. - SAITO, I. 2007. Ferulic acid restores endothelium-dependent vasodilation in aortas of spontaneously hypertensive rats. In American Journal of Hypertension, vol. 20, no. 5, pp. 508-513. DOI: 10.1016/j. amjhyper.2006.11.008

THOMPSON, L.U. 1994. Antioxidants and hormone-mediated health benefits of whole grains. In Critical Reviews in Food Science and Nutrition, vol. 34, no. 5-6, pp. 473-497.

TORRES Y TORRES, J.L. - ROSAZZA, J.P.N. 2001. Microbial transformations of $p$-coumaric acid by Bacillus megaterium and Curvularia lunata. In Journal of Natural Products, vol. 64 , no. 11, pp. 1408-1414. DOI: $10.1021 / \mathrm{np} 010238 \mathrm{~g}$

VAHER, M. - MATSO, K. - LEVANDI, T. - HELMJA, K. - KALJURAND, M. 2010. Phenolic compounds and the antioxidant activity of the bran, flour and whole grain of different wheat varieties. In Procedia Chemistry, vol. 2, no. 1, pp. 76-82. DOI: 10.1016/j.proche.2009.12.013

VAN HUNG, P. - MAEDA, T. - MIYATAKE, K. - MORITA, N. 2009. Total phenolic compounds and antioxidant capacity of wheat graded flours by polishing method. In Food Research International, vol. 42, no. 1, pp. 185-190. DOI: 0.1016/j.foodres.2008.10.005

VERMA, B. - HUCL, P. - CHIBBAR, R.N. 2008. Phenolic content and antioxidant properties of bran in 51 wheat cultivars. In Cereal Chemistry, vol. 85, no. 4, pp. 544-549. DOI: 10.1094/CCHEM-85-4-0544

VOLKAN, A.Y. - BRANDOLINI, A. - HIDALGO, A. 2015. Phenolic acids and antioxidant activity of wild, feral and domesticated diploid wheats. In Journal of Cereal Science, vol. 64, pp. 168-175. DOI: https://doi.org/10.1016/j. jcs.2015.05.005

WILLCOX, J.K. - ASH, S.L. - CATIGNANI, G.L. 2004. Antioxidants and prevention of chronic disease. In Critical reviews in Food Science and Nutrition, vol. 44, no. 4, pp. 275-295. DOI: $10.1080 / 10408690490468489$

YU, L. - PERRET, J. - HARRIS, M. - WILSON, J. - HALEY, S. 2003. Antioxidant properties of bran extracts from "Akron" wheat grown at different locations. In Journal of Agricultural and Food Chemistry, vol. 51, no. 6, pp. 1566-1570. DOI: $10.1021 / \mathrm{jf0} 20950 \mathrm{z}$

YU, V. - VASANTHAN, T. - TEMELLI, F. 2001. Analysis of phenolic acids in barley by high-performance liquid chro- 
matography. In Journal of Agricultural and Food Chemistry, vol. 49, no. 9, pp. 4352-4358. DOI: 10.1021 /jf0013407 ZHAO, Z. - MOGHADASIAN, M.H. 2010. Bioavailability of hydroxycinnamates: a brief review of in vivo and in vitro studies. In Phytochemistry Reviews, vol. 9, no. 1, pp. 133-145.

ZHOU, K. - SU, L. - YU, L.L. 2004. Phytochemicals and antioxidant properties in wheat bran. In Journal of Agricultural and Food Chemistry, vol. 52, no. 20, pp. 6108-6114. DOI: $10.1021 / \mathrm{jf0} 49214 \mathrm{~g}$
ZUCHOWSKI, J. - JONCZYK, K. - PECIO, L. - OLESZEK, W. 2011. Phenolic acid concentrations in organically and conventionally cultivated spring and winter wheat. In Journal of the Science and Food Agriculture, vol. 91, no. 6, pp. 1089-1095. DOI: 10.1002/jsfa.4288

Received: June 29, 2017 